\title{
Aggressive Behavior Psychological and Islamic Perspective
}

\author{
Novia Solichah ${ }^{1}$, Ermita Zakiyah $^{2}$, Nurul Shofiah ${ }^{3}$ \\ \{noviasolichah@uin-malang.ac.id ${ }^{1}$ \} \\ Faculty of Psychology, UIN Maulana Malik Ibrahim Malang, Indonesia ${ }^{1,2,3}$
}

\begin{abstract}
Aggressive behavior can interpret as behavior that aims to hurt others. Aggressive behavior, if not prevented quickly, will have a negative impact in the future. In the Islam perspective, aggressive behavior is found in the Quran and Hadith, as explained in surah An Nisa 111. Maqasith Sharia (Purpose of sharia) is something that the teachings of Islam are the self-care and disobedience of others. This research aims to systematically identify aggressive behavior through psychological and Islamic perspectives through the Qur'an as well as the Prophet's Hadith. This research is qualitative research with a library research approach. The results of this study show that the Qur'an and Hadith provide an integrative and holistic conceptual picture of aggressive behavior. In the study of aggressive behavioral psychology that can integrate with the approach of the Quran and Hadith. Both concepts, both psychology, and Islam, both see aggressive behavior as negative behavior because it harms others, teachings of the Quran and Hadith explain in psychology ideas. For further research with the same topic can study with Islamic figures who are concerned with psychology studies.
\end{abstract}

Keywords: Aggressive behavior, psychological perspective, islamic perspective

\section{Introduction}

Aggressive behavior is behavior both physically and mentally, which is do to hurt or injure others [1]. There are three forms of aggressive behavior, which divide into: 1) physically aggressive behavior, namely a condition of hatred which causes another person, object, or animal to be physically injured due to hitting, kicking, pinching, grabbing, and so on. 2) Verbal aggressive behavior, a form of hatred that can verbally harm others by insulting, mocking, harassing, and so on. 3) Relational behavior, namely subtle aggressiveness in the form of manipulation and threats to destroy relationships and psychological peace, is done by humiliating, lying, mocking, and breaking friends [2].

In Islam, aggressive behavior is classified as despicable in Arabic (akhlak madzmumah), this term is used by several books of Islamic thinkers such as Al Ghazali Kitab ihya Ulumuddin [3]. The form of madzmumah morality can relate to Allah, Rasulullah, himself, his family, society, and nature [4]. There are various kinds of despicable behavior: shirk, kufr, nifak and wickedness, arrogance and ujub, envy, cursing, the pride of yourself, and dhalim. In its integration, aggressive behavior is categorized as despicable behavior.

In a sense, dhalim [5] is quoted from Abu Husain Ahmad in the book Maqayis al Lughah, dhalim is an Arabic language whose root word consists of the letters dzâ ', lâm, and mîm have two original meanings, the first is to place something is out of place and the second is the 
opposite of a ray of light. Dzalim and the words with the same roots are repeated 289 times, and the sign is that dzalim is something that many people often do.

In the Qur'an dzalim has several meanings, including in several chapters as follows: $\mathrm{Al}$ Baqarah 165 and Huud 101, worshipers other than Allah. Al Maaidah 47, who made lust as god and harmed others. Al Kahfi 35, a character of his arrogance and disbelief. Al-Anbiyaa '13, the wrongdoer when he felt the punishment of Allah ran away, Al' Ankabuut 46, denied and In the Hadith, the behavior of dhalim is a matter that is shunned in the Hadith, this is like the Hadith of Qudsi in the hadith book of Arbain Nawawi, about the prohibition of doing wrong with one another. From Abu Dhar Al Ghifari radhiallahuanhu from Rasulullah Sallallahu Alayhi wa Sallam as he narrated from Allah Azza Wajalla 18): O my servant, in fact I have forbidden injustice to Myself and I have decreed its haram (injustice) among you, so do not you do wrong each other. [6]

Aggressive behavior is one indicator in people with behavioral and emotional disorders. If the aggressive behavior is repeated and persists. Children who experience behavioral and emotional disorders have obstacles in adapting to their environment. [7] Children with high levels of aggression are often diagnosed as having disruptive behavior problems (DBP). DBP is characterized by a lack of self-control over emotions and behavior, a persistent pattern of violating others' fundamental rights and breaking basic societal norms/rules. This includes aggression towards people or animals, destruction of property, and lying and theft.

A rise in youth crime and delinquency suggests that children's aggression and related behaviors are severe. Aggressive behavior in school-age children increases the risk of peer rejection, drug abuse, and neglect in the future. Besides, longitudinal research indicates that aggressive behavior is more consistent over time than any other behavioral pattern. Approximately 5-15\% of children between 5-11 years of age display clinically aggressive behavior [7]. For this reason, there needs to be a more in-depth study of aggressive behavior from a psychological and Islamic perspective.

\section{Method}

The method used in this research is qualitative research with the type of research library research. The approach used in this research is the integration-interconnection approach, where the science of religion (al ulum al-din) and psychology are interconnected, mutually correcting, and mutually reinforcing. Interconnection of scientific disciplines aims to provide openness between the concept of psychology and the science of religion, derived from the Koran and alHadith, to dialogue and complement each other. The interconnections carried out in this study are connecting Islam through the Qur'an and the Hadith of the Prophet, which explains aggressive behavior with psychological studies.

\section{Result and Discussion}

\subsection{Presenting the results}

\subsubsection{What is aggressive behavior?}


Aggressive behavior has been a focus of research due to the psychological and social consequences associated with it.[8] Aggressive behavior can be interpreted as behavior that aims to hurt others. Aggressive behavior is divided into physical, verbal, and relational.

\subsubsection{Physical aggressive}

Physical aggressiveness is the aggressiveness that is used to injure another person physically. For example, kicking, hitting, and stabbing.[1] In Islam, aggressive behavior is a form of sin. Allah SWT does not allow people to hurt each other. In al-Qur'an surah al-Ahzab verse 58 Allah SWT "And those who hurt the believers and the believers without any mistakes they have done, then they have borne lies and sins that are evident. Rasulullah SAW also ordered us as Muslims always to keep our mouths and hands, so we don't hurt others". This can be seen in the Hadith of Abu Musa Al-Asy'ari ra "I asked Rasulullah SAW," O Messenger of Allah, which of the Muslims is the most devoted? ", He said (answered)," One who can keep his hands and tongue. " The Hadith shows the importance of guarding our mouths and hands.

\subsubsection{Verbal aggressive}

Verbal aggressiveness is a form of hostility that is done to hurt others verbally, breaking using words. For example, swearing, taunting, and yelling [1]. A Muslim deserves to keep his name so that our speech is protected from dirty words, as well as stories that can hurt others or cause enmity. Because indeed, Allah SWT has ordered his servant to say excellent and right words. This is in accordance with Allah SWT's friman in al-Qur'an surah al-Ahzab verses 7071.

\subsubsection{Relational aggressive}

Relational Aggression (relational aggression) is behavior that causes harm to others by damaging (or threatening to damage) relationships or support, friendship, or group ties. Examples of Relational Aggression, namely: (1) Direct control (such as: "you are not my friend anymore, if ...") (2) social alienation (by providing hidden threats), (3) Rejection (such as by spreading rumors so that the group rejects it), (4) Social exclusion (exclusion from the game or social group).[1] In social interaction, Islam has never positioned individuals because of social strata, skin color, ethnicity, seniority. Islam explicitly states that humans were created from different ethnic groups to know each other and do good deeds. The statement is by the letter AlHujurat / 49: 13).

\subsubsection{Factors of aggressive behavior}

Factors of aggressive behavior from two points of view, namely biological and behavioral. A physical perspective will pay attention to how hormones, temperament, brain, and nervous system impact aggressive behavior. While those who emphasize behavioral perspectives will pay attention to how environmental variables can corroborate aggressive actions [13].

Three factors of the environment influence aggression behavior: the learning process, reinforcement, and imitation of the model [2]. Imitation is the impersonation of the figure model so that all its behavior becomes modeled[14]. In the modeling process, children tend to imitate specific figures, one of which is the parent because it becomes the closest figure to the child[14]. The results explain the factors that cause children to experience emotional and behavioral 
disorders due to parental treatment of the subject [15]. The most consistent set of predictors was gender, family actions against violence, peer violence, anger, academic performance, and alcohol use.[16] Besides, figures from media spectacles such as television [17] and video games[18].

Islam is in line with the approach of psychology in terms of factors that influence aggressive behavior that comes from the environment, families with home metaphors, in this case as described in the Hadith of the Prophet (peace and blessings of Allaah be upon him) 'alaihi wa

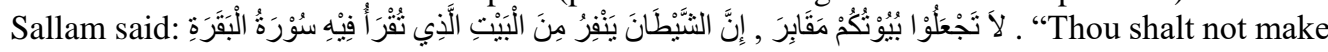
your house like a tomb; Surely Satan is running away from the house which is recited in it." In his book, the Shahîh, narrated by the Muslim Imam in his Shahîh in Musafirin Prayer's book (1821).

In another reference also described the environment as one of the factors that influence the behavior of a person, From Abu Hurairah, that the Prophet 'alaihi wa Sallam said: الرَّجُلْ عَلَى دِيْنِ

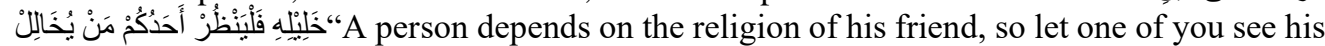
friends hanging out" Shahîh, narrated by Imam Abu Dawud in his Sunan (4833), at-Tirmidhi in his Sunan (2379), and he said: "This hadeeth Hasan," and Imam Ahmad in his Musnad, 2/ 303, 334.

\subsubsection{What is the impact of aggressive behavior?}

Aggressive behavior can hurt both the psychic and physical. With the effects of aggressive behavior, children will have difficulty interacting with peers [9]. The effect of aggressive behavior affects their social interactions with peers and the function of children in emotional and behavioral development, but it also affects academic achievement. [10] Aggressiveness in childhood is a risk factor for future growth. Individuals accustomed to aggressive actions will form their pattern in solving problems more likely to use violence, and individuals become difficult to control emotions. Coping is less useful [11].

Aggressive behavior is predictive of delinquency in adolescence and adulthood, including dropping out of school and acting out behaviors.[8] Aggressive behavior and comorbid externalizing problems (i.e., disruptiveness, non-compliance, hyperactivity, impulsivity) during childhood have been found to predict a host of adjustment problems such as peer rejection and delinquency substance abuse, school drop-out, unemployment and depression [11].

Aggressive behavior in the view of Islamic perspective, shows that Islam strongly prohibits things that can harm others and harm themselves, said Allah surah An-Nisa: 111. It means: "Whoever sins, he does it for himself. and Allah is All-Knowing, All-Wise." The impact of aggressive behavior, according to Islam, the individual will get sin and harm himself and the environment. The interpretation of the letter an-Nisa 111 can be interpreted with the verse has similarities in another letter, namely surah al-Anám 164, in the science of interpretation of this science is called muhasabah science, or it can also be included in the interpretation with the method maudhuí, with the understanding that an aggressive person will harm himself, someone who aggressively has a fear of having psychological problems, in Islam aggressive acts have a succession of impacts from which has the most impact, such as committing the murder described in QS al-Isra (17:33). Under it there is persecuting QS al-Shura (42: 40 and 42), harm in QS alBaqarah (2:57), injustice in QS al-Zukhruf (43:72), theft in QS Joseph (12:75). 


\subsubsection{How to prevent aggressive behavior?}

Aggressive behavior cannot be allowed, and it is necessary to try to control it so that there is no negative impact on the child that can continue into adulthood [19]. Here are some preventive measures in dealing with aggressive behavior problems and obtaining an earlier model of handling aggressive behavior, namely Islamic storytelling, good anger management, and Islamic counseling.

First, Islamic storytelling is the activity of listening to Islamic stories that instill excellent and bad teachings, which are prohibited and can be done by religious teachings, thus shaping one's morals to be fair and control behavior, not to commit aggressive behavior. Based on Solichah's research, which shows that listening to stories can overcome the emergence of aggressive behavior and teach social skills to children [20]. The result of Widayanti's result [21] found that the habits of storytelling parents can prevent children's negative behavior in preschool age and form a child who has moral intelligence. In Islam, many stories of prophets can be used as role models for children as examples of positive behavior.

Second, the need to further research on the influence of good anger management. [22] In Islam, when anger is suppressed with patience, the person wins the fight against his impulses and desires[23]. In Islam, aggressive behavior is given a solution in the form of a ban on anger and strengthening the desire with extensively studied[24], from the verses of the Qur'an and hadiths of valid Bukhari, which are absolute truths and other hadiths with varying qualities. As in Surah Yusuf verse 53.

Third, Islamic counseling. Counseling in Islam is an activity to provide guidance, lessons, and guidelines to individuals who ask for advice (counselee) in terms of how a counselee should be able to develop the potential of his mind, psyche, faith, and belief and can overcome the problems of life and life properly and correctly independently paradigmatic to the Al-Qur'an and As-Sunnah of the Prophet Muhammad [25]. Based on Irwanto's research results, it was shown that the application of Islamic counseling to adolescents who behave aggressively is very impactful. Aggressive adolescents who are given Islamic counseling can change their mindset to practice social norms in Islam, namely responding to Hablun Minallah Wa Hablun Minannas and practicing Muslim personality or behavior. [26] Zubair dan Azhar [27] suggested several strategies to reduce aggressive behavior according to Islamic Sharia, namely (1) Prompting the Concept of believing in the hereafter, (2) Transcendent Decency and Forgiveness, and (3) Reconciling.

First, Prompting the Concept of believing in the hereafter. Al-Quran Al- Quran has informed us that we are responsible for what we do, for what we say. We will be asked on the Day of Judgment about all these activities. We will be rewarded if we use our organs and faculties in the best way and for the peace. And we will be penalized if we use them in the wrong way. The Holy Quran 50:18 and Quran: 17:36. Narrated Sahl bin Sa'd: Allah's Messenger said, "Whoever can guarantee the chastity of what is between his two jaw-bones and what is between his two legs (i.e., his mouth, his tongue, and his private parts), I guarantee Paradise for him (Bukhārī, 1997)."

Second, Transcendent Decency and Forgiveness. Islam requires its followers to be polite when interacting with each other. If the people are hostile, then forgiveness is a basic value and principle that is always upheld in Islam. Rasulullah was often reminded and taught to seek great gifts from Allah, one being patient and forgiving others. Allah ordered the faithful believers to be patient at the time of anger and excuse those who badly treat them. Quran: 41:34 and Quran: 42:40. 
Third. Reconciling, peace is one of the central teachings in Islamic teachings. The commandment always be at peace is not only found in the verses of the Qur'an but is also exemplified in the life of the Prophet.

\subsection{Discussion}

Aggressive behavior is behavior that aims to hurt others. These forms of aggressive behavior include physical, verbal, and relational. In Islam, aggressiveness is the actualization of spiritual disease, spiritually moves dynamically and keeps on moving, [28] the role of al-qalb, al-álaq and the nafs in the spiritual will determine the state of mind, which is the basis for every behavior that arises.

The explanation of the existence of these spiritual energies was explained by al-Ghozali (1058-1111) by illustrating below:

The soul is like land. Its fields are the two hands, two legs, and all the other parts of the body. The lord of the land is sexual desire (Shahwat), and the lust for aggression (ghadab) is the guardian. Al-Qalb is the king and al-áql is the prime minister. A king must consult with his ministers to make the landlord submit to the prime minister's order for the sake of the prosperity of the country. Thus al-Qalb always consults with al-áql to bring lust and ghazab under his command. On the other hand, if the mind is under al-ghadab and lust, then the soul is destroyed, and al-qalb becomes the wretched One in the hereafter.

Al-Ghazali, [29] The heart has naturally ready to accept inner vibrations of good and evil, the whisper of malaise and Satan, both fictions according to al-Ghazali, have an equally strong position in influencing spirituality. When both lust and ghazab are obeyed, then the devil has power over him, and negative behavior occurs, the devil builds up the influence of anxiety in the heart. If lust and ghazab are restrained, then the inner decision will appear positive.

Aggressive behavior is formed from biological and behavioral factors (environment). Islam is in line with the approach of psychology in terms of factors that influence aggressive behavior that comes from the environment, families with home metaphors, in this case as described in the Hadith of the Prophet (peace and blessings of Allaah be upon him) 'alaihi wa Sallam said: "Thou shalt not make your house like a tomb; Surely Satan is running away from the house which is recited in it." In his book, the Shahîh, narrated by the Muslim Imam in his Shahîh in Musafirin Prayer's book (1821). In another reference also described the environment as one of the factors that influence the behavior of a person, From Abu Hurairah, that the Prophet 'alaihi wa Sallam said: الرَّجُلْ عَلَى دِيْنِ “'A person depends on the religion of his friend, so let one of you see his friends hanging out" Shahîh, narrated by Imam Abu Dawud in his Sunan (4833), at-Tirmidhi in his Sunan (2379), and he said: "This hadeeth Hasan," and Imam Ahmad in his Musnad, 2/ 303, 334.

This aggressive behavior makes it difficult to interact with peers. Problems in emotional and behavioral development also affect academic achievement because solving problems is done using violence. The impact of aggressive behavior, according to Islam, the individual will get sin and harm himself and the environment. The interpretation of surah An-Nisa 111 can be interpreted with a verse that has similarities in another chapter, namely surah al-Anám 164, in the science of performance this science is called Muhasabah science, or it can also be included in interpretation by the maudhuí method, with the understanding that someone is aggressive will harm himself, someone who is aggressive tends to have psychological problems, in Islam aggressive actions have an impact that is explained in a row from the One that has the most significant impact, such as committing the murder described in QS al-Isra (17: 33), then in 
underneath there is persecuting QS al-Shura (42: 40 and 42), endangering in QS al-Baqarah (2: 57), injustice in QS al-Zukhruf (43: 72), theft in QS Yusuf (12:75).

One of the Islamic teachings to deal with aggressive behavior is Islamic storytelling, good anger management, and Islamic counseling. Anger is a predisposing factor for aggressive behavior, and anger is parallel to the impulse of aggression, so it is necessary to intervene in anger to reduce one's aggressive behavior. Good anger management. From an Islamic perspective, anger management can be done through ablution, zikr, Prompting the Concept of believing in the hereafter, Transcendent Decency and Forgiveness, and Reconciling.

\section{Conclusion}

Based on this research, it can conclude that the study of the Quran and Hadith on aggressive behavior correlates with the study of psychology, where aggressive behavior is a behavior that tends to be negative. The factors that influence this behavior are biological and environmental. If not prevented and dealt with quickly, this behavior will have a negative impact in the future. Aggressive behavior can be detrimental to himself as well as others. Therefore, in Islam, aggressive behavior is classified to the deeds of Dhalim, which in the sense of language means the closed path of truth. Several precautions can be taken in the view of Islam and psychology, namely Islamic storytelling, Islamic counseling, and good anger management through ablution, dhikr, Prompting the Concept of believing in the hereafter, forgiveness, and reconciles.

In the acknowledgment section, both psychology and Islam, both see aggressive behavior as negative behavior because it harms others, and if it is not prevented quickly, it will have a negative impact in the future. Islam's perspective from the Quran and Hadith are explained in the concept of psychology. For further research with the same topic can study with Islamic figures who are concerned with psychology studies. The author says thanks to reviewers and proofreaders and the team who help this article done.

\section{References}

[1] A. Pérez et al., Aggression, time, and understanding, vol. 5, no. 1. 2017.

[2] K. Lorenz, On Agression. 2002.

[3] R. Anwar, Akhlak Tasawuf. Bandung: CV Pustaka Setia, 2010.

[4] A. J. M. Zainuddin, Al-Islam 2: Muamalah dan Aklak. Bandung: Pustaka Setia, 1999.

[5] Irfan, "Konsep al-z\}ulm dalam al-qur'an," UIN Alauddin Makassar, 2011.

[6] M. Y. B. S. Nawawi, Hadis Arbain Nawawi. Maktab Dakwah dan Bimbingan Jaliyat Rabwah, 2010.

[7] H. Potchebutzky, M. Bat Or, E. E. Kourkoutas, and M. Smyrnaki, "The Subjective Experience of Children with Disruptive Behavior Problems as Reflected in 'Person Picking an Apple from a Tree' Drawings," J. Creat. Ment. Heal., vol. 15, no. 1, pp. 2-16, 2020, doi: 10.1080/15401383.2019.1635060.

[8] D. Warman and C. Robert, "stability of aggressive behavior.pdf," Willey-liss, vol. 26, no. 1, pp. 277-290, 2000.

[9] N. H. Ali and D. S. Utami, "Efektivitas Buku 'Pelangi Hatiku' Dalam Menurunkan Agresi Siswa Sekolah Dasar," J. Interv. Psikol., vol. 5, no. 1, pp. 59-74, 2013, doi: 10.20885/intervensipsikologi.vol5.iss1.art4.

[10] Salmiati, "Jurnal Psikologi Pendidikan \& Konseling PERILAKU AGRESIF DAN PENANGANANNYA,” J. Psikol. Pendidik. Konseling, vol. 1, no. iii, pp. 66-76, 2015. 
[11] F. Vitaro, M. Brendgen, and E. D. Barker, "Subtypes of aggressive behaviors: A developmental perspective,” Int. J. Behav. Dev., vol. 30, no. 1, pp. 12-19, 2006, doi: 10.1177/0165025406059968.

[12] G. Carlo, M. V. Mestre, P. Samper, A. Tur, and B. E. Armenta, "Feelings or cognitions? Moral cognitions and emotions as longitudinal predictors of prosocial and aggressive behaviors," Pers. Individ. Dif., vol. 48, no. 8, pp. 872-877, 2010, doi: 10.1016/j.paid.2010.02.010.

[13] H. Ma'ruf, Perilaku Agresi Relasi Siswa Di Sekolah: Mengenal dan Menyelesaikannya melalui Mediasi Sebaya. Yogyakarta: Aswaja Pressindo, 2015.

[14] E. Katsurada and A. I. Sugawara, "Moderating effects of mothers' attribution on the relationships between their effect and parenting behaviors and children's aggressive behaviors," J. Child Fam. Stud., vol. 9, no. 1, pp. 39-50, 2000, doi: 10.1023/A:1009407631426.

[15] A. A. A. W. D. Anggaswari and I. G. A. P. W. Budisetyani, "Gambaran Kebutuhan Psikologis pada Anak dengan Gangguan Emosi dan Perilaku (Tinjauan Kualitatif dengan Art Therapy sebagai Metode Penggalian Data)," J. Psikol. Udayana, vol. 3, no. 1, pp. 86-94, 2016, doi: 10.24843/jpu.2016.v03.i01.p09.

[16] R. C. Swaim, K. L. Henry, and K. Kelly, "Predictors of aggressive behaviors among rural middle school youth,” J. Prim. Prev., vol. 27, no. 3, pp. 229-243, 2006, doi: 10.1007/s10935-006-0031-2.

[17] L. R. Huesmann and et al, "Mitigating the imitation of aggressive behaviors by changing children's attitudes about media violence,” J. Pers. Soc. Psychol., vol. 44, no. 5, pp. 899-910, 1983, doi: 10.1037/0022-3514.44.5.899.

[18] D. A. Gentile, P. J. Lynch, J. R. Linder, and D. A. Walsh, "The effects of violent video game habits on adolescent hostility, aggressive behaviors, and school performance," J. Adolesc., vol. 27, no. 1, pp. 5-22, 2004, doi: 10.1016/j.adolescence.2003.10.002.

[19] A. Pérez et al., Aggressivity, narcissism, and self-destructiveness in the psychotherapeutic, vol. 5, no. 1.2017.

[20] N. Solichah, "Storytelling untuk mengatasi perilaku agresif anak," Al Qalb J. Psikol. Islam, vol. 11, no. June, p. 2, 2020.

[21] S. Y. M. Widayanti, "Kebiasaan Mendongeng Orangtua dan Perilaku Negatif pada Anak Usia Prasekolah,” J. PKS, vol. 15, no. 3, pp. 295-306, 2016.

[22] L. Siddiqah, "Pencegahan dan Penanganan Perilaku Agresif Remaja Melalui Pengelolaan Amarah (Anger Management)," Pencegah. dan Penanganan Perilaku Agresif Remaja Melalui Pengelolaan Amarah (Anger Manag., vol. 37, no. 1, pp. 50-64, 2015, doi: 10.22146/jpsi.7692.

[23] A. W. Hasan, Spiritualitas sabar dan syukur, 1st ed. Yogyakarta: DIVA Press, 2019.

[24] M. Takdir, Psikologi Syukur. Jakarta: PT Elex Media Komputindo, 2018.

[25] A. D. dan M. H. Bakran, Konseling dan Psikoterapi Islam. Yogyakarta: Fajar Pustaka Baru.

[26] Z. Irwanto, "Perilaku agresif dan penanganannya melalui konseling islami," J. Psikol. Pendidik. dan Konseling J. Kaji. Psikol. Pendidik. dan Bimbing. Konseling, vol. 3, p. 27, 2017, doi: 10.26858/jpkk.v0i0.2995.

[27] H. Muhammad Zubair and H. Hussain Azhar, "Islamic Sharia Teachings and Practices for Preventing Bullying,” Am. Int. J. Contemp. Res., vol. 4, no. 1, pp. 254-265, 2014, [Online]. Available: www.aijcrnet.com.

[28] A. Sodiq, Prophetic Character Building. Jakarta Timur: Kencana, 2018.

[29] Al-Ghazali, Ihya'Ulum al Din, 3rd ed. Surabaya: al-Hidayah.

[30] M. Muhibbudin, Terapi \& Muhasabah Hati. 2019: Mueeza, 2019.

[31] S. Willis, Remaja dan masalahnya. Bandung: Alfabeta, 2012.

[32] D. Baron, R.A. \& Byrne, Social Psychology: Understanding Human Interaction. Boston: Allyn and Bacon, 2014.

[33] L. Noorfitriyani and U. Pertahanan, "Aggressive Behavior Prevention : the Effect of Peace Education and Media Literacy Towards Student 'S Understanding About," pp. 1-20. 